\title{
Long-term hay meadow management maintains the target community despite local-scale species turnover
}

\author{
Elizabeth R. Sullivan • Ian Powell • Paul A. Ashton
}

Received: 3 August 2017 / Revised: 00 Month 0000 / Accepted: 22 February 2018 / Published online: 22 May 2018

(C) The Author(s) 2018. This article is an open access publication

\begin{abstract}
Hay meadows, which are managed using a low-intensity regime, are characterized by highly diverse vegetation but have declined significantly since the mid twentieth century. Remaining species-rich meadows are often protected by statutory designations and conservation management agreements. However, long-term studies of change in the composition of meadow vegetation, and investigations of the success of conservation over the long-term are rare. Fourteen sites, which had a long history of being managed for field dried hay, were resurveyed after 25 years and redundancy analysis was undertaken to investigate changes in community composition. Investigations of the effect of soil conditions, site size and spatial distribution of the meadow sites were carried out. Although overall community composition had changed significantly, the suite of species representative of the meadow community had been maintained, and species usually associated with more intensively managed grasslands had declined. However, there were losses of particular species of conservation importance such as Alchemilla glabra and Conopodium majus, and losses and gains
\end{abstract}

Electronic supplementary material The online version of this article (https://doi.org/10.1007/s12224-018-9322-7) contains supplementary material, which is available to authorized users.

E. R. Sullivan $(\varangle) \cdot$ I. Powell $\cdot$ P. A. Ashton

Department of Biology, Edge Hill University, St Helens Road, Ormskirk, Lancashire L39 4QP, UK

e-mail: sullivae@edgehill.ac.uk of species varied from site to site. There was a significant increase in the homogeneity of the meadow vegetation between the two survey years. Comparisons of indicators of soil conditions suggested that there had been no significant change for the community as a whole but analyses of the species showing the most change indicated a decrease in soil fertility. Low-intensity management has been successful in maintaining the meadow community but consideration of changes in key species and losses at the site level is needed. More research is needed to establish whether fragmentation is starting to have an impact on diversity.

Keywords Community composition · Conservation management $\cdot$ Hay meadows $\cdot$ Homogeneity $\cdot$ Scale

Nomenclature follows Stace (2010) for vascular plants and Rodwell (1992) for plant communities.

\section{Introduction}

Grasslands of high nature value support some of the most diverse vegetation in Europe but they have seen a marked decline since the middle of the twentieth Century (Eriksson et al. 2002; Hodgson et al. 2005; Poschlod et al. 2005). Changing agricultural practices are the primary reason for this decline with intensification and abandonment resulting in reductions in biodiversity in grasslands although the pace of change in grassland habitats has differed from 
country to country (Baur et al. 2006; Dallimer et al. 2009; Otero et al. 2013). Grasslands of high nature value vary according to soil type, climatic conditions, altitude or local agricultural tradition (Küster and Keenleyside 2009). This study focuses on mesotrophic meadows which are characterized by a low-input management regime with an annual hay cut and low-intensity spring and autumn grazing (Crofts and Jefferson 2007). At lower altitudes such meadows have been particularly vulnerable to agricultural intensification and cultivation because they were often located on sites which could be easily ploughed or drained. The resulting loss has meant that existing meadows are now highly fragmented (Peterken 2013; Eriksson and Cousins 2014).

Meadows which have a history of extensive management can support high levels of floristic diversity with over 30 species per square metre on the richest mesotrophic sites (Smith 2010). The contribution of such habitats to international and national biodiversity has been acknowledged and many sites have been given statutory protection or included in agri-environment schemes (Jefferson 2005). There is some concern, however, that these conservation measures are not maintaining the biodiversity of the sites they are designed to protect (Kleijn et al. 2006) and there is an increasing demand for evidence to justify the resources required for managing agricultural land for conservation (Batáry et al. 2015).

The underlying mechanisms that enable diversity and variation in species composition in grassland ecosystems have been the subject of debate for some time (Yang et al. 2015). Factors which have been shown to influence diversity in grasslands include: levels of soil nutrients and moisture (Hejcman et al. 2014; Timmermann et al. 2015); the timing of mowing, and the timing and intensity of grazing (Smith et al. 1996); and the isolation of species-rich sites from sites supporting similar species (Krauss et al. 2004; Reitalu et al. 2009). The impacts of changes in nutrient levels, management regimes or fragmentation could be reflected in a reduction in species richness, a change in particular types of species or functional groups, or a loss of local distinctiveness in grassland vegetation (Č́amská and Skálová 2012; Homburger and Hofer 2012; Wesche et al. 2012).

Obtaining evidence for the impact of change in grasslands requires a long-term approach because there will be a time lag in the response of vegetation to alterations in management or environmental factors (Helm et al. 2006). Such an approach is central to our understanding of the drivers of change in our most valued habitats, yet there is a limited availability of long-term ecological change data (Burt 1994; Morecroft et al. 2009). Long-term experimental plots such as the Park Grass experiment (Silvertown et al. 2006) are an important source of ecological data which have been collected regularly and systematically, and which can be analysed with a degree of precision (Lindenmayer and Likens 2012). There are clear advantages in this approach to the long term study of ecological change, but there are also limitations in terms of the low numbers of experimental plot sites and such experimental sites only cover small areas (Hédl 2007). Re-surveys of more extensive areas using historical data are a valuable addition to these studies since they increase our understanding of vegetation dynamics and ecological processes both spatially and temporally (Kapfer et al. 2017).

The value of re-visitation studies has been demonstrated in analyses of the response of vegetation communities to alterations in soil chemistry (McGovern et al. 2011), changes in fertilizer application (Liira et al. 2012) or fragmentation of sites (Arponen et al. 2013) at various spatial scales. In previous re-visitation studies the focus has often been the substantial change in grassland community composition in regions where more intensive farming practices have replaced low input management (Prince et al. 2012; Wesche et al. 2012; Krause and Culmsee 2013). Some studies of vegetation in meadows which have a long history of extensive management have investigated particular aspects of change such as the homogenization of meadow vegetation (Bühler and Roth 2011) and the loss of rare meadow species (Bradshaw 2009). Only a small number of long-term studies have concentrated on meadows managed for both agricultural and conservation objectives. Critchley et al. (2007) considered the relationship between different aspects of management and vegetation change by looking at meadows in agri-environment schemes (AES) surveyed in 1987 and revisited in 2002. Since then there has been limited published evidence for the effectiveness of EU agri-environment schemes in meadows. The present study investigates long-term change in meadows which have all been managed 
for a hay crop but which were first surveyed prior to agri-environment management agreements or to the notification of statutory protection and thus addresses a significant gap in the literature.

In this study changes in plant communities in grasslands managed as meadows over a 25-year period were investigated. Data were obtained from sites first surveyed in the 1980s and repeat surveys were carried out in 2012. An analysis of overall community composition and species turnover was undertaken, and change in a particular suite of species which are representative of a mesotrophic meadow community was investigated. Change in soil conditions was assessed using Ellenberg indicator values since soil data was not collected in the original survey.

The study addressed the following questions: (1) What patterns of change can be identified in the community composition of meadow sites over 25 years? (2) Has a low-input management regime conserved species representative of a species rich hay meadow community? (3) What influence have soil conditions, site size and isolation had on the meadow community? (4) What are the implications for future conservation management?

\section{Material and methods}

Study area

The study sites are located in an area of approx. 17,000 ha in the Forest of Bowland in northern England at $53^{\circ} 58^{\prime} \mathrm{N}, 2^{\circ} 26^{\prime} \mathrm{W}$ (see Fig. 1). Climate and nitrogen deposition data are given (Table S1 in the Electronic Supplementary Material). Most of the meadows in the study are located at an altitude of 150-200 m a.s.l. with a small number of meadows at lower levels. See Table 1 for site details.

Three of the meadow sites form part of the North Pennine Dales Meadows Special Area of Conservation (SAC) and nine meadows have the national statutory designation of Sites of Special Scientific Interest (SSSI). The meadows are described as belonging to the TrisetoPolygonion alliance or are associated with alliances within the Molinio-Arrhenatheretea order (Rodwell et al. 2007). Within the UK National Vegetation Classification they support MG3 Anthoxanthum odoratumGeranium sylvaticum, MG4 Alopecurus pratensis-
Sanguisorba officinalis and MG5 Cynosurus cristatusCentaurea nigra communities (Rodwell 1992).

All of the sites are protected and/or in an agrienvironment scheme so their management involves a late hay cut (after 15 July for AES sites) followed by field drying of the hay for 3-4 days and baling. Aftermath grazing is carried out in the late summer/early autumn and the meadows are grazed in the spring until they are 'shut up' to allow the hay crop to grow. Livestock are removed for a period of time before the hay cut (usually a minimum of 8 weeks) and a limited amount of farmyard manure may be spread on the sites. (Natural England 2010, 2017a, b). There will be minor variations in the management regime because of weather conditions and the type of livestock on each farm.

Field survey and data collection

Surveys of semi-natural grassland were carried out in England in the 1980s and 1990s and the results were compiled into a Grassland Inventory for England (Jefferson et al. 1997; Blackstock et al. 1999). The detailed survey records for the county of Lancashire survive in their original form, and it is these records which were the baseline for this study. From these inventory records 14 sites were identified in the Bowland region, which had been consistently managed as meadows since the 1980 s. In the original surveys the sites had been described as species-rich meadow communities, which suggests that the low input meadow management regime had been established well before the original survey was undertaken. In most cases this was confirmed by the farmers who owned or rented the sites. References were made to their classifications as MG3, MG4 or MG5 grassland although the surveys took place before the publication of the British National Vegetation Classification for grasslands in 1992 (Rodwell 1992).

The guidance for the original surveys (hereafter the 'first survey') stated that $1-\mathrm{m}^{2}$ quadrats should be placed randomly within a stand of vegetation judged to be representative of the meadow community (Smith et al. 1985). The numbers of quadrats varied according to the size of the site but in total 55 quadrat surveys were recorded across the 14 sites. In these quadrats all vascular plants were recorded using the Domin scale of cover-abundance. The survey record cards also 


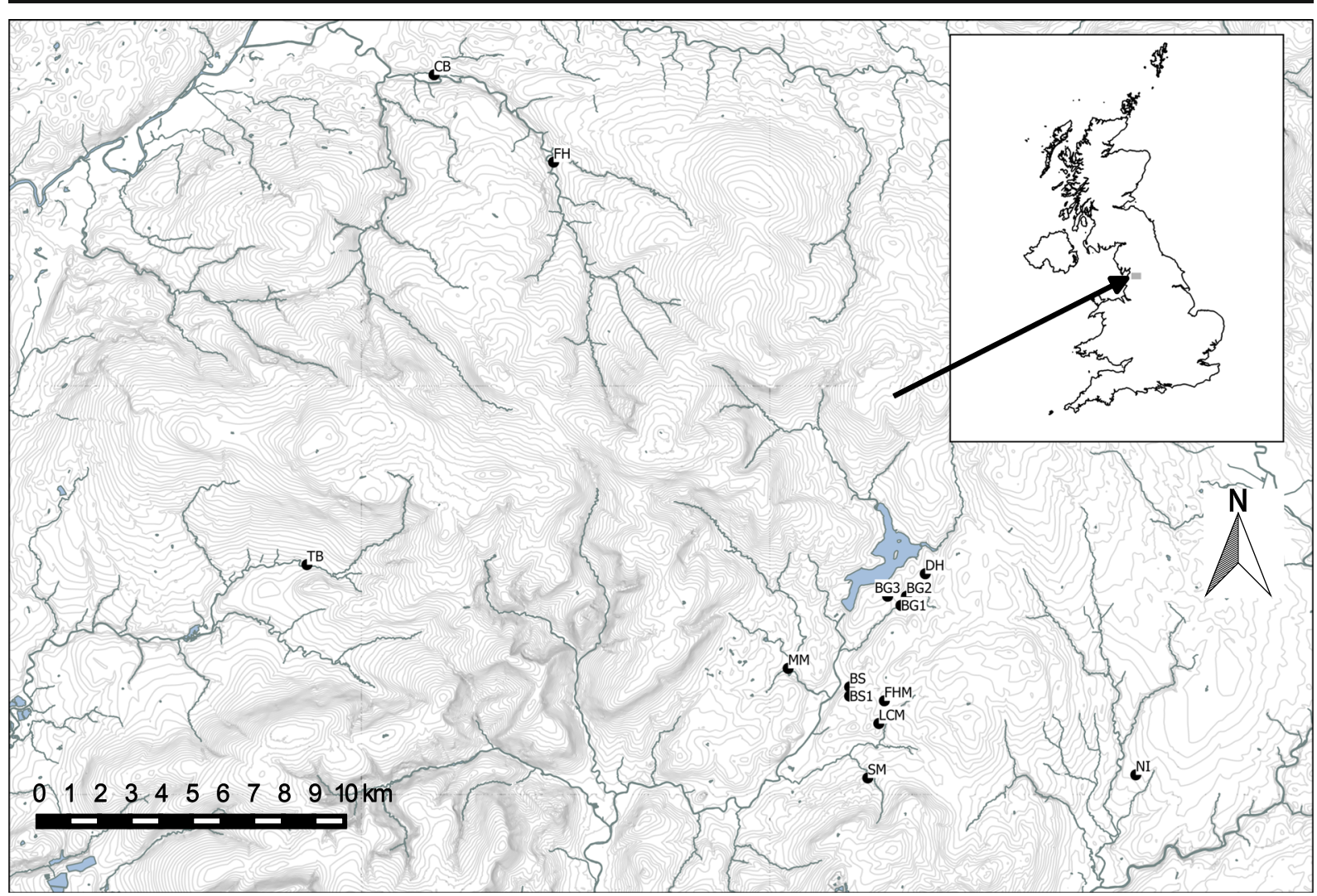

Fig. 1 Location map and study sites.

included sketch maps which showed the locations of the quadrats in each field (Smith et al. 1985).

Copies of the original record cards were used to locate the approximate positions of the quadrats and the surveys were carried out using the original methodology. Most of the sites consist of individual fields and the larger sites are sub-divided into field units so it was possible to place the quadrats within a few metres of the original locations. In addition the meadow sites have a relatively uniform sward so choosing an area which was representative of the whole stand was straightforward. Tests for plot relocation accuracy were applied to the quadrats from a random selection of four of the meadow sites following the method developed by Ross et al. (2010). Wilcoxon rank sum tests showed that there was significantly greater dissimilarity between the first and repeat survey quadrats compared with the dissimilarity between the repeat survey quadrats $(P<0.001)$. The repeat surveys (the 'second survey') were carried out in the summer of 2012 as closely as possible to the original survey dates and were completed by mid-July to ensure that they were completed before the hay cut. All of the 55 quadrats from the first survey were re-surveyed and the locations of the second survey quadrats were recorded using a handheld GPS and the survey data will be deposited in the Edge Hill University's Research Archive (available at https://repository.edgehill.ac.uk).

Soil data was not collected during the first survey so changes in soil conditions were compared using Ellenberg indicator values (EIVs) for the British flora (Hill et al. 1999). EIVs give a proxy value for soil conditions including soil moisture, $\mathrm{pH}$ and fertility based on scores awarded to vascular plants. Cover weighted and non-weighted EIVs were compared across the sites but there was little difference in the results so non-weighted scores were used in the analysis. The size of the sites were calculated in hectares (ha) and isolation of sites was calculated by measuring the straight line distance in $\mathrm{km}$ between one meadow and the closest neighbouring meadow in the dataset (nearest neighbour distance). Some sites were adjacent to other sites but were analysed separately if they had a statutory designation (see Table 1). 
Table 1 Details of meadow sites and information about area in hectares, nearest neighbour distance in kilometres, altitude in metres above sea level and site designation

\begin{tabular}{lllll}
\hline Site ID & $\begin{array}{l}\text { Site area } \\
{[\mathrm{ha}]}\end{array}$ & $\begin{array}{l}\text { Distance to nearest } \\
\text { meadow site }[\mathrm{km}]\end{array}$ & $\begin{array}{l}\text { Elevation } \\
{[\mathrm{m} \text { a.s.l. }]}\end{array}$ & $\begin{array}{l}\text { Statutory } \\
\text { designation }\end{array}$ \\
\hline BG & 5.47 & 0.01 & 180 & SSSI \\
BG2 & 2.2 & 0.01 & 180 & None \\
BG3 & 3.1 & 0.13 & 180 & None \\
BS & 7.65 & 0.01 & 150 & SAC/SSSI \\
BS1 & 2.3 & 0.01 & 180 & None \\
CB & 0.54 & 3.49 & 60 & SSSI \\
DH & 0.4 & 0.78 & 190 & None \\
FH & 1.63 & 3.49 & 105 & SSSI \\
FHM & 3.33 & 0.46 & 210 & SSSI \\
LCM & 5.26 & 0.46 & 190 & SAC/SSSI \\
MM & 9.09 & 1.29 & 155 & SAC/SSSI \\
NI & 2.09 & 6.13 & 125 & SSSI \\
SM & 3.63 & 1.2 & 200 & None \\
TB & 11.87 & 11.59 & $155-180$ & SSSI \\
\hline
\end{tabular}

SAC - Special Area of Conservation (European designation), SSSI - Site of Special Scientific Interest (UK designation)

Percentage cover of key meadow species was recorded as a subset of the overall data set. Species used as both target and non-target species for meadow vegetation in condition assessments of UK species rich grasslands were included in this subset (JNCC 2004) along with species used in a study by Kirkham et al. (2014), which compared change in an upland and lowland meadow. In the UK context the Bowland meadows are mainly upland sites but some are found at lower levels so these lists of species were found to be particularly relevant to the present study. A full list of target and non-target species is found in Table S2 in the Electronic Supplementary Material.

\section{Data analysis}

All statistical analyses were carried out in $\mathrm{R}$ version 3.1.2 (R Development Core Team 2014). Tests for normality of distribution and homogeneity of variance were carried out where appropriate. Domin scores in both surveys were converted to a percentage cover value using the Domin 2.6 transformation (Currall 1987 ) to avoid over emphasising rare species.
To analyse differences in community composition between the two surveys redundancy analysis (RDA) was carried out using the vegan package in $\mathrm{R}$ (Oksanen et al. 2013). The data were transformed using the Hellinger transformation (Legendre and Gallagher 2001) and the RDA was performed with survey year as the explanatory variable and site as a covariable. The analysis was repeated using presenceabsence data to assess the addition information provided by an assessment of qualitative change between the two survey years.

A permutation test was used to indicate the level of statistical significance of the final model (minimum permutations $=1,000$ ). It was not necessary to use a blocked design for the permutation test because the effect of site was partialled out in the model so the permutation procedure of the test was model-based. The data structure was, therefore, not included within the permutation test since sites were treated as covariables in the analysis. The eigenvectors (species scores) returned by the model were used to establish which species had contributed most to the variance in species composition. The species which were the most associated with each of the two survey years based on the magnitude of the eigenvectors were extracted from the model output and an analysis was made of which species had increased or decreased in terms of frequency of records on each site between the two survey years. Species scores were also extracted from the RDA results for the presence-absence data although the same scores were often shared by several species due to the use of binary data in the analysis.

To investigate change in site species richness the mean number of species per site was calculated and the difference between the two survey years was tested using a paired $t$-test.

To investigate patterns in the diversity of the meadow community vegetation a test for multivariate homogeneity of group dispersions was carried out using the betadisper function in vegan followed by a permutation test for significance (Anderson et al. 2006; Oksanen et al. 2013). This function involves the calculation of distances between the principal coordinates of dissimilarity coefficients to group centroids. In this case the Bray Curtis dissimilarity index was used because it takes account of relative abundances and has the necessary properties for the analysis of betadiversity (Legendre and De Cácares 2013). The groups were the two survey years. 
Analyses of changes in soil conditions were carried out by using permutation tests on unweighted mean Ellenberg indicator values for soil moisture (EIV moisture), $\mathrm{pH}$ (EIV pH) and fertility (EIV fertility). The permutation tests followed the method developed by Zelený and Schaffers (2012), which was designed to overcome the bias associated with analysis of EIVs when they are compared using parametric tests or used as explanatory variables in constrained ordination. Wilcoxon signed rank tests were used in a comparison of the mean EIVs of the most influential species in the RDA analysis. The permutation test could not be used in this case because two different sets of species were compared.

Differences in percent cover of target and non-target meadow species by site was tested by a Wilcoxon signed rank test to account for a non-normal distribution. The effects of site size, nearest neighbour distance and altitude on relative change in cover of target meadow species were tested using a linear regression model in which relative change $=\frac{(\text { Percentcover } \in \text { secondsurvey-percentcover } r \text { firstsurvey })}{\text { percentcover } \in \text { secondsurvey }}$. Checks were carried out to ensure the residuals met the model's assumptions. The model was also run with site frequency counts of target species and with change in cover and frequency of non-target species.

\section{Results}

Ninety-five species were recorded across the 14 meadow sites in the first survey whereas 79 species were found in the second survey. Site richness was significantly lower in the second survey than it was in the first survey (see Table 3). Twenty-five species were found only in the first survey and not in the second, and nine species were found in the second survey but not in the first. In most cases these losses and gains were due to records at only one site (see Table 2) but in some of the species that were absent from the second survey there were three or more records in the first survey (Achillea ptarmica, Anemone nemorosa, Ranunculus bulbosus and Vicia sepium).

Results of the RDA showed that there was a significant difference $(P=0.003)$ between the community composition of the meadow sites in the first survey compared with that of the second survey (Fig. 2). Survey year accounted for $11.26 \%$ of the variance and the adjusted $R^{2}$ value was 0.08 .
The species scores for the first axis were extracted from the RDA output and were ranked according to their magnitude. The 10 species with the lowest negative eigenvector scores (most associated with the first survey) and the 10 species with the highest negative scores (most associated with the second survey) are shown in Table 2. Table 2 shows whether these species increased or decreased in terms of the frequency of sites in which they were recorded. Target and non-target meadow species are also identified. Some target species decreased such as Conopodium majus and Alchemilla glabra whilst others increased such as Euphrasia species, Scorzoneroides autumnalis and Rhinanthus minor. There were also decreases in some non-target species, e.g. Bromus hordeaceus, Phleum pratense and Lolium perenne, whilst others such as Ranunculus repens, Juncus articulatus and Holcus lanatus saw an increase. Decreases also occurred in common grasses such as Poa trivialis, which is not considered to be a non-target and there were increases in widespread grassland species such as Plantago lanceolata and Trifolium pratense.

The RDA model with presence absence data was also significant $(P=0.007)$ although less variance was explained by survey year $(5.78 \%$ in the presence-absence model, compared with $11.26 \%$ in the abundance data model). The adjusted $R^{2}$ for the presence-absence model was relatively low at 0.02 . Patterns in the ordination plot (Fig. S1 in the Electronic Supplementary Material) were similar to those in Fig. 2 and some of the species which were most associated with each of the survey years in the abundance RDA (Table 2) were also among the most influential species in the presence-absence analysis (see Table 2).

The analysis of homogeneity of community composition in the two sites revealed that mean distances between centroids had decreased from 0.42 to 0.36 (see Fig. 3) and the permutation test revealed that the differences between the distances were significant $(P$ $=0.04)$. This result indicates that the vegetation has become more homogenous over the survey period.

There was no significant difference in any of the mean EIVs between the two survey years (Table 3) suggesting that differences in soil conditions were minimal. However, when a comparison of the mean EIVs of the ten species most associated with the first survey and the ten most associated with the second survey (listed in 
Table 2 Species only recorded in the first or second survey with the number of site records in parentheses; species most associated with each survey in the RDA of abundance data using the highest and lowest eigenvector scores and with the change in site frequency in parentheses; species most associated with the RDA of species-absence data using the highest and lowest eigenvector scores

\begin{tabular}{|c|c|c|}
\hline & First survey & Second survey \\
\hline $\begin{array}{l}\text { Species only recorded in either the } 1 \text { st or } 2 \text { nd } \\
\text { survey (number of site records) }\end{array}$ & $\begin{array}{l}\text { Achillea ptarmica (5), Ranunculus bulbosus } \\
\text { (4), Anemone nemorosa (3), Vicia sepium } \\
\text { (2), Alchemilla xanthochlora* (2), Festuca } \\
\text { ovina (2), Heracleum sphondylium\# (2), } \\
\text { Schedonorus pratensis (2), Agrostis } \\
\text { canina (1), Ajuga reptans (1), Briza media } \\
\text { (1), Carex pulicaris (1), Cirsium arvense\# } \\
\text { (1), Festulolium loliaceum (1), Geranium } \\
\text { pratense (1), Geranium sylvaticum* (1), } \\
\text { Holcus mollis (1), Hyacinthoides } \\
\text { non-scripta (1), Juncus acutiflorus\# (1), } \\
\text { Juncus bufonius\# (1), Juncus inflexus\# (1), } \\
\text { Koeleria macrantha (1), Montia fontana } \\
\text { (1), Rumex obtusifolius\# (1) }\end{array}$ & $\begin{array}{l}\text { Carex flacca (1), Carex leporina (1), Cirsium } \\
\text { palustre (1), Danthonia decumbens (1), } \\
\text { Glyceria fluitans (1), Luzula multiflora } \\
\text { (1), Pedicularis palustris (1) Potentilla } \\
\text { anserina (1), Trifolium campestre (1) }\end{array}$ \\
\hline $\begin{array}{l}\text { Species most associated with each survey in } \\
\text { RDA analysis using abundance data } \\
\text { (change in site frequency in parentheses) }\end{array}$ & $\begin{array}{l}\text { Poa trivialis }(-2), \# \text { Bromus hordeaceus }(-5), \\
\quad \text { \#Phleum pratense }(-5), * \text { Conopodium } \\
\text { majus }(-3), \text { Poa pratensis }(-3), \\
\text { *Alchemilla glabra }(-5), \text { Luzula } \\
\text { campestris }(-4), \text { Alopecurus pratensis } \\
(-2), \text { \#Lolium perenne }(-1), \text { Cerastium } \\
\text { fontanum }(-1)\end{array}$ & $\begin{array}{l}\text { \#Ranunculus repens }(+9), * \text { Euphrasia sp.div. } \\
\text { (+6), Plantago lanceolata }(+1), \\
\text { *Scorzoneroides autumnalis }(+5), \\
\text { \#Juncus articulatus }(+3), \text { Trifolium } \\
\text { pratense }(+3), \text { Cynosurus cristatus }(+3), \\
\text { \#Holcus lanatus }(+1), * \text { Rhinanthus minor } \\
(+1), \text { Carex nigra }(0)\end{array}$ \\
\hline $\begin{array}{l}\text { Species most associated with each survey in } \\
\text { RDA analysis using presence-absence } \\
\text { data. Species in bold were also species } \\
\text { with the lowest negative or highest } \\
\text { positive eigenvector scores in the RDA } \\
\text { analysis of abundance data }\end{array}$ & $\begin{array}{l}\text { Achillea ptarmica, Alchemilla glabra*, } \\
\text { Bromus hordeaceus\#, Dactylis } \\
\text { glomerata\#, Ficaria verna, Phleum } \\
\text { pratense\#, Bellis perennis, Luzula } \\
\text { campestris, Ranunculus bulbosus, } \\
\text { Anemone nemorosa, Cardamine pratensis, } \\
\text { Centaurea nigra }{ }^{*}, \text { Conopodium majus } * \\
\text { Equisetum arvense, Poa pratensis, Vicia } \\
\text { sepium }\end{array}$ & $\begin{array}{l}\text { Ranunculus repens\#, Euphrasia sp.div.*, } \\
\text { Scorzoneroides autumnalis, Cynosurus } \\
\text { cristatus, Juncus articulatus\#, Myosotis } \\
\text { discolor, Trifolium pratense, Agrostis } \\
\text { capillaris, Prunella vulgaris, Trifolium } \\
\text { dubium, Potentilla anserina, Rhinanthus } \\
\text { minor, Stellaria graminea, Trifolium } \\
\text { campestre, Trisetum flavescens, Vicia } \\
\text { cracca }\end{array}$ \\
\hline
\end{tabular}

Species marked with an asterisk (*) are target meadow species. Species marked with a hash symbol (\#) are non-target meadow species

Table 2) was undertaken, there were significant differences (see Table 3). In this analysis of the most influential species EIV moisture increased, EIV reaction increased and EIV fertility decreased. Site richness was significantly lower in the second survey than it was in the first survey (Table 3). An analysis of the change in the percentage cover of target meadow species between the first and second surveys did not reveal a significant difference but there was a significant decline in the percentage cover of non-target species (see Table 3).

The linear regression model for the effects of site size, nearest neighbour distance and altitude on relative change in cover of target species did not indicate any significant results $(P=0.158, P=0.222$ and $P=0.438$, respectively). There were no significant effects shown when the model was run with change in frequency counts of target species nor with non-target species. However, plots of change in percentage cover of target meadow species by location (Fig. 4a and b) showed that cover had decreased at the more isolated sites whilst sites which were closer together with had seen increases.

\section{Discussion}

Patterns of change in community composition

The analysis of meadow sites between the two survey years has shown that there has been a significant change in community composition, and that this change has been brought about by a reduction in non-target meadow species and by turnover in some of the key target species which are 


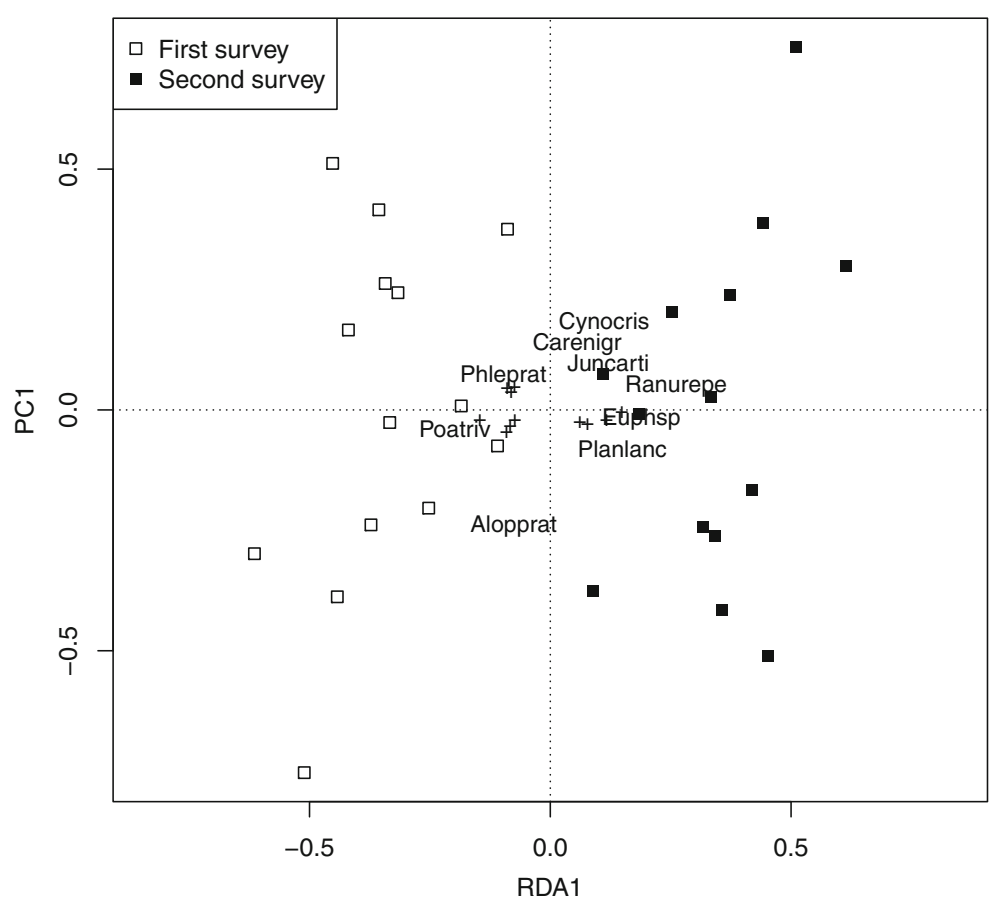

Fig. 2 RDA ordination plot of meadow sites constrained by year. Square symbols show sites in first and second survey. Ten species most associated with first and second survey are shown. Alchglab - Alchemilla glabra; Alopprat-Alopecurus pratensis; Bromhord - Bromus hordeaceus; Carenigr - Carex nigra; Cerafont Cerastium fontanum; Conumaju - Conopodium majus; Cynocris - Cynosurus cristatus; euphsp - Euphrasia species; Holclana -

representative of the meadow community. The cover of target meadow species as a whole appears to have been maintained but there has been an increase in homogeneity across the study sites.

\section{Reduction in non-target species}

Thirteen of the fourteen meadows sites are managed through an agri-environment scheme (AES) and nine are protected through a statutory designation. These measures allow limited amounts of farmyard manure to be applied but prohibit the use of inorganic fertilizers. There is substantial evidence to show that increased soil fertility encourages the growth of competitive grasses, particularly on sites with a history of low input management (Mountford et al. 1993; Smith et al. 2003; Kirkham et al. 2014), so it would be expected that limiting fertility would restrict non-target species such as Lolium perenne and Phleum pratense, which were shown to decrease in the study area.
Holcus lanatus; Juncarti - Juncus articulatus; Lolipere - Lolium perenne; Luzucamp - Luzula campestris; Phleprat - Phleum pratense; Planlanc - Plantago lanceolate; Poaprat - Poa pratensis; Poatriv - Poa trivialis; Ranurepe-Ranunculus repens; Rhinmino - Rhinanthus minor; Scorautu - Scorzoneroides autumnalis; Triprat - Trifolium pratense.

It is also notable that two hemiparastic herbs Euphrasia species and Rhinanthus minor have shown an increase in the frequency of sites on which they were recorded. The ability of hemiparasitic species to suppress competitive grasses has been demonstrated in studies of meadow restoration (Bullock and Pywell 2005), so it is possible that these two species have played a role in the reduction of non-target species. Overall there was a reduction in the cover of non-target species (Table 2), but there were increases and decreases in the frequency of individual species indicating that the overall pattern is not reflecting the detailed change at the individual site and species level.

\section{Turnover in target meadow species}

The analysis of percentage cover of target meadow species across the study area showed that there was no significant difference between the two survey 


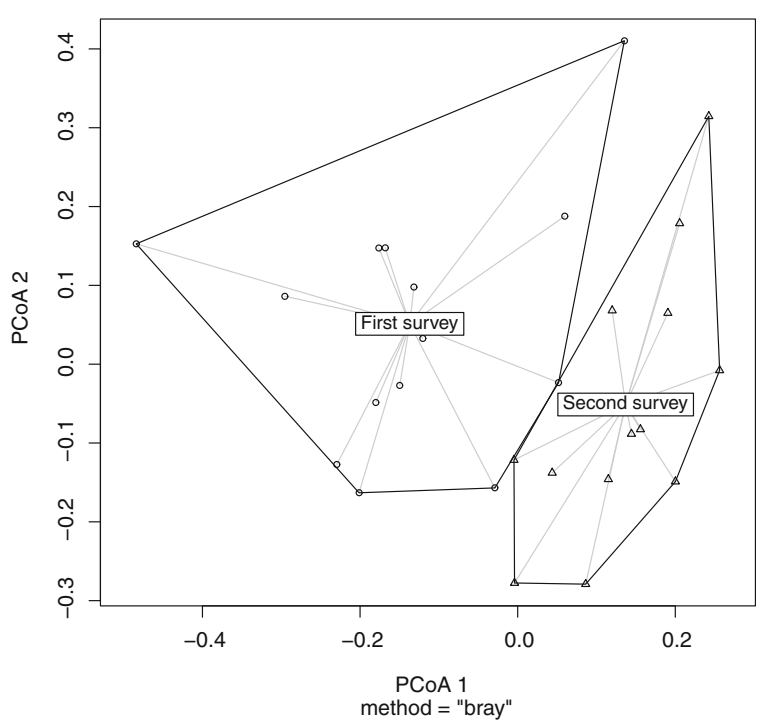

Fig. 3 PCoA plot showing analysis of homogeneity of multivariate dispersions using betadisper function with Bray Curtis distance matrix. The mean distances to the centroid was 0.42 for first survey and 0.36 for the second survey.

years but it is clear that there are 'winners' and 'losers' among the target species. For example Alchemilla glabra, which has seen a decline, is a constant species in the upland hay meadow community (MG3) (Rodwell 1992). A. glabra is declining nationally particularly at the southern edge of its range in northern England and parts of Wales (Preston et al. 2002). Studies of upland hay meadows in northern England have linked change in key target meadow species primarily to management, habitat quality and fragmentation (Critchley et al. 2007; Pacha and Petit 2008; Bradshaw 2009) but higher temperatures resulting from climate change may become more of a concern for the northern montane species in the future so monitoring of such species is important for conservation.

A study of hay meadows by Valkó et al. (2012) found that mowing was needed to limit graminoid biomass but that some species were supressed by mowing. These species included Achillea ptarmica, which was only present in the first survey and was one of the most influential species in the RDA when analysed by presence-absence. It was suggested that greater diversity in the meadow sward could be achieved by introducing variations in mowing regimes, eg, by including fallow years or leaving unmown strips. Whilst this approach may not be as attractive in terms of agricultural productivity it may reflect more closely the pattern of meadow management prior to the introduction of AES. Farmers may have chosen to mow earlier or later depending on levels of spring growth, weather conditions or even availability of labour (Eriksson et al. 2015). The use of a standardized cutting date applied to whole regions of northern England has been linked with a widespread increase in annual species such as Euphrasia species. The regular pattern of later cutting is thought to allow annuals to set seed every year whereas prior to the introduction of AES dates would have varied with some years being less favourable for annuals (O’Reilly 2010; Starr-Keddle 2014). Several other annual species which were among those most associated with the second survey in the RDA presence-absence analysis (e.g. Myosotis discolor, Trifolium dubium and Trifolium campestre), suggesting that management has favoured several annual species in the study region.

Standardized cutting dates are also linked to the dates when livestock are removed from the meadows in the spring. AES prescriptions require that the meadows are 'shut up' eight weeks before mowing, which would equate to mid-May in the study region which has an earliest cutting date of 15 July. However, a study by Smith et al. (2016) has shown that the removal of livestock earlier in the spring had a positive effect on species diversity and benefitted early flowering species including Anemone nemorosa, Ficaria verna and Luzula campestris, all of which were more closely associated with the first survey.

There has also been concern that the use of a standardized approach could be linked to the loss of local distinctiveness or increased homogenization in species rich grasslands (Homburger and Hofer 2012). Bühler and Roth (2011) found that taxonomic homogenization was a result of an increase in more common species. Examples in this study could be Scorzoneroides autumnalis, Trifolium pratense and Prunella vulgaris, which are common grassland 'generalists'. It is likely that a longer time period is needed to assess such changes particularly in grasslands where most of the species are perennials (Bühler and Roth 2011). In addition to the indication of greater homogenization at the regional level, the significant decrease in site species richness suggests that within-site diversity has also declined. The need to balance regionally applied management prescriptions, which appear to maintain the overall suite 
Table 3 Comparison of site richness by year; changes in Ellenberg indicator values (EIV): $\mathrm{F}$ (moisture), $\mathrm{R}$ (pH) and $\mathrm{N}$ (fertility) for all species and most influential species in RDA analysis; percent cover of target and non-target meadow species

\begin{tabular}{|c|c|c|c|}
\hline & \multirow[t]{2}{*}{ Test } & \multicolumn{2}{|l|}{ Result } \\
\hline & & First survey & Second survey \\
\hline \multirow[t]{2}{*}{ Site species richness } & Mean (standard error) & $31.71(2.78)$ & \multirow[t]{5}{*}{$27.64(2.36)$} \\
\hline & Paired $t$-test & $t=1.56, P=0.005^{* *}$ & \\
\hline Moisture EIV (all species) & Modified permutation test & $F=0.96, P=0.307(\mathrm{NS})$ & \\
\hline pH EIV (all species) & Modified permutation test & $F=3.05, P=0.066(\mathrm{NS})$ & \\
\hline Fertility EIV (all species) & Modified permutation test & $F=2.26, P=0.111(\mathrm{NS})$ & \\
\hline \multirow{2}{*}{$\begin{array}{l}\text { Moisture EIV (10 most influential } \\
\text { species from each survey) }\end{array}$} & Median & 5.29 & \multirow[t]{2}{*}{5.55} \\
\hline & Wilcoxon signed rank & $W=26, P<0.001 * * *$ & \\
\hline \multirow{2}{*}{$\begin{array}{l}\text { pH EIV (10 most influential } \\
\text { species from each survey) }\end{array}$} & Median & 5.95 & \multirow[t]{2}{*}{6.13} \\
\hline & Wilcoxon signed rank & $W=52.5, P=0.04 *$ & \\
\hline \multirow{2}{*}{$\begin{array}{l}\text { Fertility EIV (10 most influential } \\
\text { species from each survey) }\end{array}$} & Median & 5.59 & \multirow[t]{2}{*}{4.38} \\
\hline & Wilcoxon signed rank & $W=187, P<0.001 * * *$ & \\
\hline \multirow[t]{2}{*}{ Percent cover of target species } & Median & 22.36 & \multirow[t]{2}{*}{19.72} \\
\hline & Wilcoxon signed rank & $W=57, P=0.807(\mathrm{NS})$ & \\
\hline \multirow[t]{2}{*}{ Percent cover of non-target } & Median & 38.0 & \multirow[t]{2}{*}{20.75} \\
\hline & Wilcoxon signed rank & $W=86, P=0.036^{*}$ & \\
\hline
\end{tabular}

$P$ values significant at the $<0.05$ level are identified by $* P$ values of $<0.01$ are identified by $* * ; P$ values of $<0.001$ are identified by $* * *$. Non-significant results are identified by (NS)

of meadow species in the study area, with the long-term impact on floristic homogenization and local distinctiveness merits further investigation.

\section{Effect of fragmentation of grassland sites}

There were no significant relationships between site size, nearest neighbour distance and altitude with change in cover of target or non-target meadow species. It is possible that, although many of the target species are representative of meadow communities, they will also be found in other semi-natural grassland sites so populations of these species in the meadows may be less isolated than the distribution of meadow sites would suggest. However, the pattern of losses and gains in percent cover of target species by site shown in Fig. 4 could indicate that change is taking place at the site level, which is not yet statistically significant but may become increasingly important from an ecological point of view.

The loss of specialist plant species with increasing fragmentation of semi-natural grasslands has been reported in other studies (Pacha and Petit
2008; Brückmann et al. 2010). There is evidence that smaller populations of grassland specialists may be more vulnerable to fragmentation but the time taken before the effects of isolation become evident will vary depending on population sizes, time since fragmentation occurred and other factors (Kuussaari et al. 2009). The impacts of isolation in grasslands on genetic diversity and the subsequent reduction in plant fitness have been highlighted along with the need to account for slow response times to habitat fragmentation (Takkis et al. 2013). A precautionary grassland management approach which takes into account the connectivity of protected sites and other grasslands of conservation value has been recommended as the way to address the effects of isolation of grassland populations (Arponen et al. 2013).

\section{Soil conditions}

The influence of EIV values was not found to be significant in the RDA but the mean values for the species most associated with the second survey were 

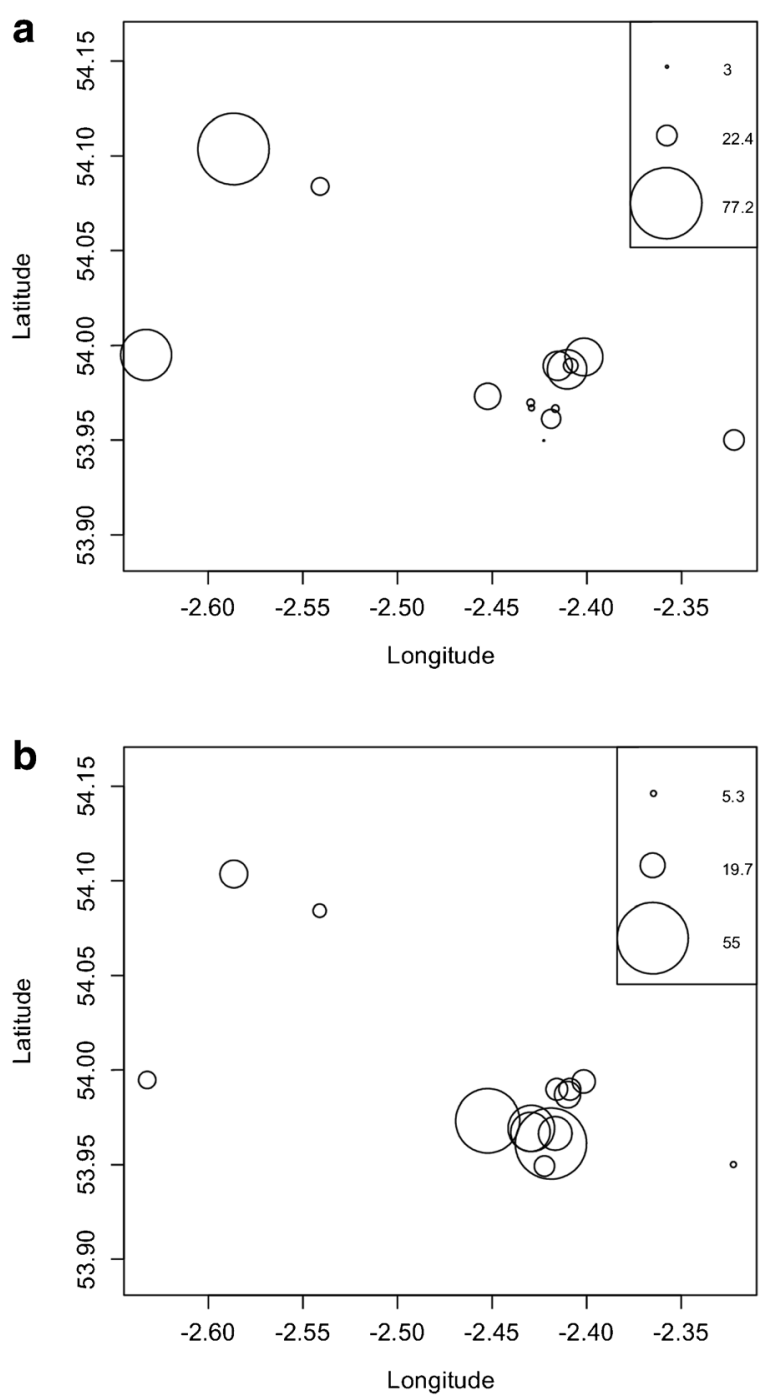

Fig. 4 a Plot of cover of target meadow species in the first survey by location. b Plot of cover of target meadow species in the second survey by location. The larger the circle, the higher the percent cover value. Scale shows range of cover values (lowest and highest values) and median value.

significantly higher than those of the most influential species in the first survey. The increases in the frequency of species such as Ranunculus repens and Juncus articulatus could be indicative of a shift towards conditions where drainage is impeded (Rodwell 1992; Lynn and Waldren 2003). The impact on soil compaction and alterations to soil hydrology resulting from the use of heavier farm machinery and from trampling by cattle has been well documented (Hamza and Anderson 2005; Kurz et al. 2006). In addition there were no options in the AES for farmers to repair or replace collapsed field drains, and the installation of new drainage systems is not permitted on protected grassland sites (Natural England 2017b). This is likely to have resulted in field drain maintenance being neglected. However, the widespread increase in $R$. repens from $25 \%$ to $84 \%$ of the quadrats indicates a distribution throughout the sward. It would be expected that localized increases in moisture associated with damaged field drains may have shown a more patchy distribution.

The nitrogen deposition value for the area (27.02 $\mathrm{kg} \mathrm{N} \cdot \mathrm{ha}^{-1} \cdot$ year $^{-1}$ ) is close to the upper limit of the critical load for low and medium altitude hay meadows, which is given as $20-30 \mathrm{~kg} \mathrm{~N} \cdot \mathrm{ha}^{-1}$.year ${ }^{-1}$ (Table S1 in the Electronic Supplementary Material), but the analysis of mean EIV fertility values did not show a significant increase from the first to the second survey and the values for both surveys were within the target range used by Smith et al. (2003) in their study of upland meadow restoration, i.e. approximately $4.3-$ 4.7 for mean EIV fertility values. Findings from other long term grassland studies have shown that the impact of nitrogen deposition on grassland vegetation appears to vary according to grassland type with notable negative impacts on species richness in acid grasslands (Stevens et al. 2010). Mesotrophic grasslands are less well studied but van den Berg et al. (2016) reported a negative relationship between nitrogen deposition and species richness in mesotrophic grasslands as well as in acid grasslands, and found that there was a positive effect on species richness in calcareous grasslands. Despite the similarity in EIV fertility values for the two survey years, the analysis of the EIVs for the most influential species in the RDA model showed a marked reduction in EIV fertility. Species such as Bromus hordeaceus, Poa pratensis and Alopecurus pratensis have high EIV fertility values and were all prominent species in the first survey. Species which were strongly associated with the second survey, such as Plantago lanceolata, Juncus articulatus and Carex nigra, have low EIV fertility values. The reduction in competitive grasses has already been discussed and can be seen as a measure of success of the conservation management of species rich grasslands. Increases in Juncus species would not be welcomed by conservation managers (Pinches et al. 2013), but, overall, lower nutrient levels are important for maintaining species diversity.

Values for EIV $\mathrm{pH}$ for the whole dataset were also similar for both surveys although the analysis of the 
most influential species showed an increase in the EIV $\mathrm{pH}$ value. Whilst acid deposition for the area did not exceed critical loads during the period of the second survey (APIS 2017), the first survey would have been undertaken at a time when acid deposition levels are likely to have been higher than at present (RoTAP 2011).

It should be noted that Ellenberg indicator values are a proxy measure and can differ from analyses of soil chemistry (McGovern et al. 2011), but they do provide a useful indication of change where soil data is not available for comparison. In the present study it appears that hay meadow management has maintained soil fertility, $\mathrm{pH}$ and moisture levels overall although the effects of nitrogen deposition and potential impacts of impeded drainage should be monitored to inform future management approaches.

\section{Conclusion}

There has been a significant change in the community composition of hay meadow vegetation in the study area but hay meadow management has maintained the overall cover of target meadow species and reduced the cover of non-target species. There have been losses of particular species which are key constituents of the hay meadow communities and the meadow vegetation has become more homogenized. The measurement of success of the conservation of hay meadows should take account of the impacts on key species and on individual sites, and consideration should be given to a more targeted approach to management prescriptions. There was no significant change in Ellenberg indicator values over the whole community although analyses of the species showing the most change indicated a decrease in soil fertility. More research is required to explore the reasons for species change and to establish whether the fragmented distribution of the meadows is affecting their long-term viability, findings which have also been identified in studies across Europe.

\footnotetext{
Acknowledgements The authors would like to thank the landowners who gave permission for the surveys to be undertaken and Natural England and the Forest of Bowland Area of Outstanding Natural Beauty team for the provision of support and information. We thank the anonymous reviewers for comments, which helped to improve the manuscript. Financial support for the project was received from Edge Hill University, Natural England, The Botanical Society of Britain and Ireland and the Natural History Museum's Botanical Research Fund.
}

Open Access This article is distributed under the terms of the Creative Commons Attribution 4.0 International License (http:// creativecommons.org/licenses/by/4.0/), which permits unrestricted use, distribution, and reproduction in any medium, provided you give appropriate credit to the original author(s) and the source, provide a link to the Creative Commons license, and indicate if changes were made.

\section{References}

Anderson MJ, Ellingsen KE, McArdle BH (2006) Multivariate dispersion as a measure of beta diversity. Ecol Letters 9:683-693

APIS (2017) Air Pollution Information System. Available at http://www.apis.ac.uk/queryLocationCheckbox-result?gridRef= SD711530\& gridType $=$ landranger $\&$ dropDownHabitat $=$ Select+a+Habitat\&pollutants $\% 5 \mathrm{~B} \% 5 \mathrm{D}=$ Acid\&pollutants $\% 5$ B\%5D=NDep\&submit=See+the+results (Accessed 1 July 2017)

Arponen A, Heikkinen RK, Paloniemi R, Pöyry J, Similä J Kuussaari M (2013) Improving conservation planning for semi-natural grasslands: integrating connectivity into agri-environment schemes. Biol Conservation 160: 234-241

Baur B, Cremene C, Groza G, Rakosy L, Schileyko AA, Baur A, Stoll P, Erhardt A (2006) Effects of abandonment of subalpine hay meadows on plant and invertebrate diversity in Transylvania, Romania. Biol Conservation 132:261-273

Batáry P, Dicks LV, Kleijn D, Sutherland WJ (2015) The role of agri-environment schemes in conservation and environmental management. Conservation Biol 29:1006-1016

Blackstock TH, Rimes CA, Stevens DP, Jefferson RG, Roberston HJ, Mackintosh J, Hopkins JJ (1999) The extent of seminatural grassland communities in lowland England and Wales: a review of conservation surveys 1978-96. Grass Forage Sci 54:1-18

Bradshaw M E (2009) The decline of Lady's-mantles (Alchemilla vulgaris L. agg.) and other hay-meadow species in Northern England since the 1950s. Watsonia 27:315-321

Brückmann SV, Krauss J, Steffan-Dewenter I (2010) Butterfly and plant specialists suffer from reduced connectivity in fragmented landscapes. $J$ Appl Ecol 47: 799-809

Bühler C, Roth T (2011) Spread of common species results in local-scale floristic homogenization in grassland of Switzerland. Diversity \& Distrib 17:1089-1098

Bullock JM, Pywell RF (2005) Rhinanthus: a tool for restoring diverse grassland? Folia Geobot 40:273-288

Burt TP (1994) Long-term study of the natural environment perceptive science or mindless monitoring? Prog Phys Geogr 18:475-496

Čámská K, Skálová H (2012) Effect of low-dose N application and early mowing on plant species composition of mesophilous meadow grassland (Arrhenatherion) in Central Europe. Grass Forage Sci 67:403-410

Critchley CNR, Fowbert JA, Wright B (2007) Dynamics of species-rich upland hay meadows with agricultural management practices. Appl Veg Sci 10:307-314 
Crofts A, Jefferson RG (eds) (2007) The lowland grassland management handbook. ( $2^{\text {nd }}$ ed.) English Nature/The Wildlife Trusts. Available at: http://publications.naturalengland.org. uk/publication $/ 35034$

Currall, JEP (1987) A transformation of the Domin scale. Vegetatio 72:81-87

Dallimer M, Tinch, D, Acs S, Hanley N, Southall HR, Gaston KJ, Armsworth PR (2009) 100 years of change: examining agricultural trends, habitat change and stakeholder perceptions through the 20th century. J Appl Ecol 46: 334-343

Eriksson O, Cousins SAO, Bruun HH (2002) Land-use history and fragmentation of traditionally managed grasslands in Scandanavia. $J$ Veg Sci 13:743-748

Eriksson O, Cousins SAO (2014) Historical landscape perspectives on grasslands in Sweden and the Baltic Region. Land 3: 300-321

Eriksson O, Bolmgren K, Westin A, Lennartsson T (2015) Historic hay cutting dates from Sweden 1873-1951 and their implications for conservation management of species-rich meadows. Biol Conservation 184:100-107

Hamza MA, Anderson WK (2005) Soil compaction in cropping systems: a review of the nature, causes and possible solutions. Soil Tillage Res 82:121-145

Hédl R (2007) Is sampling subjectivity a distorting factor in surveys for vegetation diversity? Folia Geobot 42:191-198

Hejcman M, Sochorová L, Pavlů V, Štrobach J, Diepolder M, Schellberg J (2014) The Steinach Grassland Experiment: soil chemical properties, sward height and plant species composition in three cut alluvial meadow after decades-long fertilizer application. Agric Eco-Syst Environm 184:76-87

Helm A, Hanski I, Pärtel M (2006) Slow response of plant species richness to habitat loss and fragmentation. Ecol Letters 9:72-77

Hill MO, Mountford JO, Roy DB, Bunce RGH (1999) Ellenberg indicator values for British plants. ECOFACT, vol. 2, technical annexe. ITE Monkswood, Huntingdonshire/ Department of the Environment, Transport and the Regions, London

Hodgson JG, Montserrat-Martí G, Tallowin J, Thompson K, Díaz S, Cabido M, Grime JP, Wilson PJ, Band SR, Bogard A, Cabido R, Cáceres D, Castro-Díez P, Ferrer C, Maestro-Martínez M, Pérez-Rontomé MC, Charles M, Cornelissen JHC, Dabbert S, Pérez-Harguindeguy N, Krimly T, Sijtsma FJ, Strijker D, Vendramini F, Guerrero-Campo J, Hynd A, Jones G, Romo-Díez A, de Torres Espuny L, Villar-Salvador P, Zak MR (2005) How much will it cost to save grassland diversity? Biol Conservation 122:263-273

Homburger H, Hofer G (2012) Diversity change of mountain hay meadows in the Swiss Alps. Basic Appl Ecol 13:132-138

Jefferson RG, Harniess PN, Eady PN, Owen TL, Robertson HJ, Hopkins JJ, Mortimer C (1997) Inventories of lowland grassland in England: rationale and methodology. English Nature Research Report No. 215. English Nature, Peterborough. Available at http://publications.naturalengland.org. uk/publication/210954

Jefferson RG (2005) The conservation management of upland hay meadows in Britain: a review. Grass Forage Sci 60:322-331
JNCC (2004) Common standards monitoring guidance for lowland grassland version February 2004. Joint Nature Conservation Committee, Peterborough. ISSN 17438160

Kapfer J, Hédl R, Jurasinski G, Kopecký M, Schei FH, Grytnes J (2017) Resurveying historical vegetation data - opportunities and challenges. Appl Veg Sci 20:164-171

Kirkham FW, Tallowin JRB, Dunn RM, Bhogal A, Chambers BJ, Bardgett RD (2014) Ecologically sustainable fertility management for the maintenance of species-rich hay meadows: a 12 year fertilizer and lime experiment. J Appl Ecol 51:152-161

Kleijn D, Baquero RA, Clough Y, Díaz M, De Esteban J, Fernández F, Gabriel D, Herzog F, Holzschuh A, Jöhl R, Knop E, Kruess A, Marshall EJP, Steffan-Dewenter I, Tscharntke T, Verhulst J, West TM, Yela JL (2006) Mixed biodiversity benefits of agri-environment schemes in five European countries. Ecol Letters 9: $243-254$

Krause B, Culmsee H (2013) The significance of habitat continuity and current management on the compositional and functional diversity of grasslands in the uplands of Lower Saxony, Germany. Flora 208:299-311

Krauss J, Klein AM, Steffan-Dewenter I, Tscharntke T (2004) Effects of habitat area, isolation, and landscape diversity on plant species richness of calcareous grasslands. Biodivers \& Conservation 13:1427-1439

Kurz, I, O'Reilly CD, Tunney H (2006) Impact of cattle on soil physical properties and nutrient concentrations in overland flow from pasture in Ireland. Agric Eco-Syst Environm 113: 378-390

Küster H, Keenleyside C (2009) The origin and use of agricultural grasslands in Europe. In Veen P, Jefferson $\mathrm{R}$, De Smidt J, van der Straaten J (eds) Grasslands in Europe of high nature value. KNVV Publishing, Zeist, pp 9-14

Kuussaari M, Bommarco R, Heikkinen RK, Helm A, Krauss J, Lindborg R, Öckinger E, Pärtel M, Pino J, Rodà F, Stefanescu C, Teder T, Zobel M, Steffan-Dewenter I (2009) Extinction debt: a challenge for biodiversity conservation. Trends Ecol Evol 24:564-571

Legendre P, De Cácares M (2013) Beta diversity as the variance of community data: dissimilarity coefficients and portioning. Ecol Letters 16:951-963

Legendre P, Gallagher ED (2001) Ecologically meaningful transformations for ordination of species data. Oecologia, 129: $271-280$

Liira J, Ingerpuu N, Kalamees R, Moora M, Pärtel M, Püssa K, Roosaluste E, Saar L, Tamme R, Zobel K, Zobel M (2012) Grassland diversity under changing productivity and the underlying mechanisms - results of a 10 -yr experiment. $J$ Veg Sci 23:919-930

Lindenmayer DB, Likens GE (2012) The science and application of ecological monitoring. Biol Conservation 143:1317-1328

Lynn DE, Waldren S (2003) Survival of Ranunculus repens L. (Creeping Buttercup) in an amphibious habitat. Annals BotLondon 91:75-84

McGovern S, Evans CD, Dennis P, Walmsley C, McDonald M (2011) Identifying drivers of species compositional change in a semi-natural upland grassland over a 40 -year period. $J$ Veg Sci 22:346-356 
Morecroft MD, Bealey CE, Beaumont DA, Benham S, Brooks DR, Burt TP, Critchley CNR, Dick J, Littlewood NA, Monteith DT, Scott WA, Smith RI, Walmsley C, Watson H (2009) The UK Environmental Change Network: emerging trends in the composition of plant and animal communities and the physical environment. Biol Conservation 142:2814-2832

Mountford JO, Lakhani KH, Kirkham FW (1993) Experimental assessment of the effects of nitrogen addition under hay-cutting and aftermath grazing on the vegetation of meadows on a Somerset peat moor. $J$ Appl Ecol 30:321-332

Natural England (2010) Sward enhancement: diversifying grassland by spreading species-rich green hay. Technical Information Note TIN063 Available at http://adlib.everysite. co.uk/resources/000/102/926/TIN063.pdf (Accessed 1 July 2017)

Natural England (2017a) Condition of SSSI Units for Site Bell Syke. Available at https://designatedsites.naturalengland.org. uk/ReportUnitCondition.asp $\mathrm{x}$ ? SiteCode $=$ S2000350 $\&$ ReportTitle=Bell Sykes Meadows SSSI (Accessed 1 July 2017)

Natural England (2017b) Views about management. Available at https://necmsi.esdm.co.uk/PDFsForWeb/VAM/2000350.pdf (Accessed 30 May 2017)

Oksanen, J, Guillaume Blanchet F, Kindt R, Legendre P, Minchin PR, O'Hara RB, Simpson GL, Solymos P, Henry M, Stevens H, Wagner H (2013) Vegan: community ecology package. R package version 2.0-10. Available at http://CRAN.R-project. org/package=vegan (Accessed 1 July 2017)

O'Reilly J (2010) The state of upland hay meadows in the North Pennines. Brit Wildlife 21:184-192

Otero I, Boada M, Tàbara JD (2013) Social-ecological heritage and the conservation of Mediterranean landscapes under global change. A case study in Olzinelles (Catalonia). Land Use Policy 30:25-37

Pacha MJ, Petit S (2008) The effect of landscape structure and habitat quality on the occurrence of Geranium sylvaticum in fragmented hay meadows. Agric Eco-Syst Environm 123:81-87

Peterken G (2013) Meadows. British Wildlife Publishing, Gillingham

Pinches CE, Gowing DJG, Stevens CJ, Fagan K, Brotherton PNM (2013) Natural England review of upland evidence - upland hay meadows: What management regimes maintain the diversity of meadow flora and populations of breeding birds? Natural England Evidence Review, Number 005

Poschlod P, Bakker JP, Kahmen S (2005) Changing land use and its impact on biodiversity. Basic Appl Ecol 6:93-98

Preston CD, Pearman DA, Dines TD (eds) (2002) New atlas of the British flora: an atlas of the vascular plans of Britain, Ireland, The Isle of Man and the Channel Islands. Oxford University Press, Oxford

Prince HE, Bunce RGH, Jongman RHG (2012) Change in the vegetation composition of hay meadows between 1993 and 2009 in the Picos de Europa and implications for nature conservation. J Nat Conservation 20:162-169

R Development Core Team (2014). R: A Language and Environment for Statistical Computing. Vienna, Austria: R Foundation for Statistical Computing. Available at https://www.R-project.org (Accessed 1 July 2017)
Reitalu T, Sykes MT, Johansson LJ Lönn M, Hall K, Vandewalle M, Prentice HC (2009) Small-scale plant species richness and evenness in semi-natural grasslands respond differently to habitat fragmentation. Biol Conservation 142:899-908

Rodwell JS (ed) (1992) British plant communities Volume 3: grasslands and montane communities. Cambridge University Press, Cambridge

Rodwell JS, Morgan V, Jefferson RG, Moss, D (2007) The European context of British lowland grasslands. JNCC Report 394. Joint Nature Conservation Committee, Peterborough, ISSN 09638901

Ross LC, Woodin SJ, Hester A, Thompson DBA, Birks JB (2010) How important is plot relocation accuracy when interpreting re-visitation studies of vegetation change? Pl Ecol Divers 3:1-8

RoTAP (2011) Review of transboundary air pollution: acidification, eutrophication, ground level ozone and heavy metals in the UK. Available at http://www.rotap.ceh.ac.uk (Accessed 1 November 2015)

Silvertown J, Poulton P, Johnston AE, Edwards G, Heard M, Biss PM (2006) The Park Grass experiment 1856-2006: its Contribution to ecology. J Ecol 94:801-814

Smith IR, Wells DA, Welsh P (1985) Botanical survey and monitoring methods for grasslands. Grassland Habitat Network Handbook Number 1. Nature Conservancy Council, Peterborough. Available at http://jncc.defra.gov. $\mathrm{uk} /$ pdf/Pub85_Botanical_survey_\&_monitoring_methods for_grasslands_PRINT.pdf

Smith RS, Buckingham H, Bullard MJ, Shiel RS, Younger A (1996) The conservation management of mesotrophic (meadow) grassland in Northern England: effects of grazing, cutting date and fertilizer on the vegetation of a traditionally managed sward. Grass Forage Sci 51: 278-291

Smith RS, Shiel RS, Bardgett RD, Millward D, Corkhill P, Rolph G, Hobbs PJ, Peacock S (2003) Soil microbial community, fertility, vegetation and diversity as targets in the restoration management of a meadow grassland. $J$ Appl Ecol 40:51-6

Smith R (2010) Understanding grassland systems. In Gamble D, St. Pierre T (eds) Hay Time in the Yorkshire Dales: the natural, cultural and land management history of hay meadows Scotforth Books, Lancaster, pp 145-177

Smith RS, Shiel RS, Millward D, Simkin JM (2016) Effects of sheep stocking on the plant community and agricultural characteristics of upland Anthoxanthum odoratumGeranium sylvaticum meadow in northern England. Grass Forage Sci 72:502-515

Stace CA (2010) New Flora of the British Isles. $\left(3^{\text {rd }}\right.$ ed) Cambridge University Press, Cambridge

Starr-Keddle R (2014) Upper Teesdale: changes in upland hay meadow vegetation over the past twenty to thirty years - results presented from botanical surveys. Natural England Commissioned Report NECR139. Available at http://publications.naturalengland.org. uk/publication/6301646967537664 (Accessed 5 November 2015)

Stevens CJ, Duprè C, Dorland E, Gaudnik C, Gowing DJG, Bleeker A, Diekmann M, Alard D, Bobbink R, Fowler D, Corcket E, Mountford JO, Vandvik V, Aarrestad PA, Muller S, Dise NB (2010) Nitrogen deposition threatens species 
richness of grasslands across Europe. Environm Pollut 158: 2940-2945

Takkis K, Pärtel M, Saar L, Helm A (2013) Extinction debt in a common grassland species: immediate and delayed responses of plant and population fitness. Pl Ecol 214:953-963

Timmermann A, Damgaard C, Strandberg MT, Svenning JC (2015) Pervasive early $21^{\text {st }}$-century vegetation changes across Danish semi-natural ecosystems: more losers than winners and a shift towards competitive tall-growing species. J Appl Ecol 52 21-30

Valkó O, Török P, Matus G, Tóthmérésza B (2012) Is regular mowing the most appropriate and cost-effective management maintaining diversity and biomass of target forbs in mountain hay meadows? Flora 207:303-309

van den Berg LJL, Jones L, Sheppard LJ, Smart SM, Bobbink R, Dise NB, Ashmore MR (2016) Evidence for differential effects of reduced and oxidised nitrogen deposition on vegetation independent of nitrogen load. Environm Pollut 208:890-897

Wesche K, Krause B, Culmsee H, Leuschner C (2012) Fifty years of change in Central European grassland vegetation: large losses in species richness and animal-pollinated plants. Biol Conserv 150:76-85

Yang Z, Hautier Y, Borer ET, Zhang C, Du G (2015) Abundanceand functional-based mechanisms of plant diversity loss with fertilization in the presence and absence of herbivores. Oecologica 179:261-270

Zelený D, Schaffers AP (2012) Too good to be true: pitfalls of using mean Ellenberg indicator values in vegetation analyses $J$ Veg Sci 23:419-431 